\title{
The History of Protestant Theological Education in Canada
}

\section{N. Keith Clifford}

Volume 56, 1989

Changements culturels et éducation de la foi

Cultural Change and Education of the Faith

URI : https://id.erudit.org/iderudit/1006956ar

DOI : https://doi.org/10.7202/1006956ar

Aller au sommaire du numéro

Éditeur(s)

Les Éditions Historia Ecclesiæ Catholicæ Canadensis Inc.

ISSN

0318-6172 (imprimé)

1927-7067 (numérique)

Découvrir la revue

Citer cet article

Clifford, N. K. (1989). The History of Protestant Theological Education in

Canada. Sessions d'étude - Société canadienne d'histoire de l'Église catholique, 56,

85-95. https://doi.org/10.7202/1006956ar

Tous droits réservés @ Les Éditions Historia Ecclesiæ Catholicæ Canadensis Inc., 1989
Ce document est protégé par la loi sur le droit d'auteur. L'utilisation des services d’Érudit (y compris la reproduction) est assujettie à sa politique d'utilisation que vous pouvez consulter en ligne.

https://apropos.erudit.org/fr/usagers/politique-dutilisation/ 


\title{
The History of Protestant Theological Education in Canada
}

\author{
N. Keith CLIFFORD
}

The history of Protestant theological education is a neglected aspect of the history of higher education in Canada. There are histories of a few colleges which have been inspired by anniversary occasions ${ }^{1}$. But several of the most important institutions have yet to find a historian and most of what is known about the smaller schools is confined largely to articles, pamphlets and theses ${ }^{2}$. Unfortunately the new standards of institutional history, established by recent volumes on the major institutions of higher

1 See J.W. Falconer and W.G. Watson, A Brief History of Pine Hill Divinity Hall and the Theological Department of Mount Allison University, (Halifax, 1946); Dyson Hague, et al. The Jubilee volume of Wycliffe College 1877-1927, (Toronto: Wycliffe College, 1927); Arnold Edinborough (ed.), The Enduring Word: A Centennial History of Wycliffe College, (Toronto: University of Toronto Press, 1978); George Rawlyk and Kevin Quinn, The Redeemed of the Lord Say So: A History of Queen's Theological College 1912-1972, (Kingston: Queen's Theological College, 1980); O.W. Howard, The Montreal Diocesan Theological College: A History from 1873 to 1963, (Montreal: McGill University Press, 1963); H. Keith Markell, The Faculty of Religious Studies, McGill University, 1948-1978, (Montreal: Faculty of Religious Studies, 1979). Essential information on the foundation of all Protestant Church Colleges is contained in D.C. Masters, Protestant Church Colleges in Canada: A History, (Toronto: University of Toronto Press, 1966). For an important comparaison of Canadian and American theological education, see Robert T. Handy, "Trends in Canadian and American Theological Education, 1880-1980: Some Comparisons," Theological Education, 18:2 (Spring, 1982), 175-218.

2 See, for example, J.A. Johnston, "The Presbyterian College," (McGill M.A. thesis, 1951); Mary D. Burton, "The Anglican Theological College of British Columbia 1909-1927: Unity and Diversity," (University of Alberta, M.A. Thesis, 1974; among the important articles, see J. Elliot, "The Education of the Clergy," Queen's Quarterly, 2 (1895), 229-237; W.G. Jordan, "The Standard of Ministerial Education," Queen's Quartely, 19 (1912), 202213; Jean E. Murray, "The Early History of Emmanual College," Saskatchewan History, 9:3 (1956); L.S. Thomas, "The Church of England and Higher Education in the Prairie West before 1914," Journal of the Canadian Church History Society, 3 (1956), 1-11; and especially, F.W. Peake, "Theological Education in British Columbia," Canadian Journal of Theology, 5:4 (1959), 251-262; among the important pamphlets, see Ralph C. Pybus, The Story of Union College, (Vancouver: Board of Governors Union College of British Columbia, 1971) and E. Gale, (ed.), "Jubilee Year 1960-61," Via Media, (Vancouver, 1961). 
education in Canada, such as McGill, Queen's, McMaster and Mount Allison, have not been applied to the history of Protestant theological education. Consequently, the focus of the existing material remains mainly on personalities and the framework is so exclusively denominational that it is very difficult to get an overview of the development of theological education in Canada or any sense of the changing conceptions of the ministry which have been dominant at various times in the history of Canadian Protestantism.

With the thirty minute time-limit set for these papers, it is impossible to discuss the whole history of Protestant theological education in Canada. All that is possible is to take a very brief look at three questions which would have to be addressed by anyone who was thinking of writing a history of Protestant theological education in Canada. The first of these is the transition from an apprenticeship system of ministerial training to the establishment of theological colleges. The second is the development of the theological colleges as professional schools. And the third is the emergence of the Bible Colleges as an alternative to the theological colleges in Canada. These may strike some as a curious trio, but all three questions have been ignored because of the narrow institutional focus of the existing histories of Canadian theological colleges and all three must be answered in order to place Canadian Protestant theological education in an adequate historical context.

In the history of Canadian theological education little attention has been paid to the apprenticeship system of ministerial training or what Roland Bainton has called "schools of the prophets" because institutional histories have been interested in the origins of the theological colleges rather than the manner in which theological education was carried on in the era prior to the establishment of theological colleges in Canada ${ }^{3}$. Consequently, there has been no careful examination of the apprenticeship system or of the criticisms directed against it in the nineteenth century as

3 Roland H. Bainton, Yale and the Ministry, (New York: Harper and Brothers, 1957), chps. V and VII. See also Mary L. Gambrell, Ministerial Training in 18th Century New' England, (New York: Columbia University Press, 1937) and Patricia U. Bonomi, “' 'Stewards of the Mysteries of God': Clerical Authority and the Great Awakening in the Middle Colonies," in Professions and Professional Ideologies in America, ed. by Gerald L. Geison, (Chapel Hill, University of North Carolina Press, 1983). 
the various denominations struggled to replace it with theological colleges ${ }^{4}$. This omission has meant that the changing context of theological education in Canada has not been sufficiently appreciated and the relationship between the development of theological education and other forms of professional education has been largely ignored.

In the apprenticeship system of ministerial training students went to live in the home of a minister, used his library, and followed him about on his appointed rounds until the minister thought they were ready for ordination. According to Bainton, "ministerial tutors [in Connecticut] were not selected by the college nor by the churches but were chosen by the students who often reined up at a parsonage door, unannounced, with a request for admission." If they were accepted, they became part of the minister's family and, as Bainton notes, they often "left equipped not only with wisdom but also a wife." For many of them married the minister's daughters.

In Canada, the system appears to have been somewhat more formal in the sense that church courts usually appointed one of their own ministers as a "theological professor or "tutor." In 1810, for example, James McGregor indicated that the Associate Presbytery of Nova Scotia had appointed Mr. Ross, the minister of West River, to direct the studies of the first candidate for the ministry from Pictou county. By 1814 Ross had five young men studying with him. In describing the system of training they intended to use, James McGregor said:

\begin{abstract}
Our plan is to appoint one of ourselves to teach languages, and in place of lectures in philosophy, to collect a small library of books in history, and the most useful sciences, make them read these and help by frequent examination and direction to get as good a view of them as we can, and perhaps a few lectures in Divinity. To accustom them to compose, we mean to give them subjects of discourse from time to time, beginning at an early period and continuing all along" 5 .
\end{abstract}

In 1820 Thomas McCulloch was appointed the theological professor for the United Presbyterian Church in Nova Scotia. This work was carried on in conjunction with McCulloch's work in the Pictou Academy but entirely separate from it. A year later it was reported that there were

4 See Robin S. Harris, A History of Higher Education in Canada, 1663-1960, (Toronto: University of Toronto Press, 1976). This excellent volume places the theological colleges clearly within the framework of professional education and it makes possible the comparison of the theological colleges with other professional schools. Harris has placed all scholars in his debt with his masterful bibliographies of every aspect of higher education in Canada, see Robin S. Harris and A. Tremblay, A Bibliography of Higher Education in Canada, (Toronto: University of Toronto Press, 1960) and Robin S. Harris, Supplement 1965 and Supplement 1971 to a Bibliography of Higher Education in Canada, (Toronto: University of Toronto Press, 1965 and 1971).

5 See George Patterson, Some Remains of the Rev. James McGregor, (Philadelphia: Joseph M. Wilson, 1859), 392. 
twelve students in Divinity and that they were making respectable progress 6 . Some have seen the appointment of McCulloch as a theological professor as the date for the establishment of the first theological college in Canada, but in fact this appointment was really an application of the apprenticeship system, for the twelve students who read Divinity with McCulloch were simply apprentices of the principal of a college that at times was the equivalent of a liberal arts college but at other times was little more than a high school. The failure to make this distinction, as I propose to show in what follows, can blind one to the true emergence of the theological college and stems largely from the desire of a particular institution on an anniversary occasions to be able to claim that it was the first theological college in Canada.

In 1843, when the Missionary Synod of the Canadas was formed, William Proudfoot, a minister in London, Ontario was selected to be the synod's professor. While his pastoral duties continued, he was asked to instruct students in Literature, Philosophy, and Divinity and to provide the students with room and board. For these extra duties he was granted a salary of six hundred pounds a year. Five years later Dr. Alexander Forrester was appointed by the Colonial Committee of the Free Church of Scotland to take charge of the training of candidates for the ministry in the lower provinces 7 . In all these cases what we are looking at is the apprenticeship system and the individuals who were appointed by the churches to look after the training of the apprentices.

The Presbyterian Church was not the only Protestant denomination to adopt this method of training. In 1838 the Congregational Church in Upper Canada appointed Adam Lillie, a minister at Brantford to supervise the training of candidates for the ministry in their church ${ }^{8}$. At Brantford Lillie had one student under his care but by the time he moved to Dundas in the following year he had five students. Single-handedly the Congregational Church expected Lillie to teach these young men "Latin, Greek, Hebrew, Mental and Moral Philosophy, Logic and Rhetoric, Theology, Church History, Biblical Criticism and Interpretation, Homiletics, and Pastoral Theology9." Today, it is startling to think of anyone expecting a single individual to teach all of these subjects, but what is even more remarkable is that Adam Lillie did it from 1838 to 1869 when he finally

6 Minutes of the Proceedings of the Presbyterian Church of Nova Scotia. (June 28. 1821).

7 The Preshyterian Witness and Evangelical Advocate, (February 5, 1848).

8 For biographical information on Adam Lillie (1803-1896) see Earl B. Eddy, "Lillie, Adam" Dictionary of Canadian Biography, vol. 9, (Toronto: University of Toronto Press, 1976), 467-468.

9 F.H. Marling, Congregational College of British North America: The Story of the Fifty Years 1839-1889, (Montreal: "Witness" Printing House, 1889), 10. 
dropped dead. Moreover, from 1838 to 1840 he did it while carrying out his pastoral duties as well. From the perspective of our current era of specialization, such an expectation seems totally absurd but what is even more awe inspiring is that Lillie could not fudge it by saying that someone was ready when he wasn't ready because the church examined all candidates for ordination and they did it at a public oral examination where anyone was welcome to participate in the examination of the candidates.

Fortunately an account of one of these examinations, which took place during the meetings of the Congregational Union of Upper Canada in 1842, has survived and it reveals that these examinations bore little resemblance to the perfunctory questioning which candidates for ordination receive in most denominations today. It consisted of three parts: first, the reading of classical texts such as the Odes of the Greek poet Anacreon and the Latin historian and biographer Cornelius Nepos which was followed by questioning on the grammatical construction of these works and other matters; second, questions from the chairman Mr. Roach and the tutor, Adam Lillie, on "Miracles and Prophecy, the primitive constitutions and early state of the Christian churches, the influences that led to their corruption, the growth of the Papal System, the precursors of the Reformation etc., etc.; and finally, each student was required to give a brief address on such topics as "The Claims of the Young on the Christian Ministry" and "The Special Requisites for the Ministry at the Present Time."

Between 1842 and 1852 the Anglicans also used this system for the Diocesan Theological Institute at Cobourg, which was under the direction of Alexander Bethune and was essentially a one man operation that had all the attributes of "a school of the prophets." The students lived in Bethune's rectory and he fitted in their instruction around his own pastoral duties ${ }^{10}$. While these few references are far from a complete survey of this system of ministerial training, I think they are enough to establish that this method was adopted by all the Protestant denominations in Canada. In Britain and the United States it was common for most candidates to take a university degree before entering this apprenticeship system but prior to the 1840s there were no universities or liberal arts colleges in which the majority of Canadian Protestants could receive Arts degrees. Consequently, all the training which candidates for the ministry received had to be handled in this way.

10 See J.D. Purdy, "John Strachan and the Diocesan Theological Institute at Cobourg, 1842-1852," Ontario History, 65 (1973), 113-123. For the development of the English theological colleges, see Owen Chadwick, The Victorian Church, Part I, (Oxford: Oxford University Press, 1966), 140 and 504. See also Owen Chadwick, "The Development of Theological Education," in The Journey Continues: The Diamond Jubilee Lectures at VST, ed. by R. Gerald Hobbes, (Vancouver: Vancouver School of Theology, 1988), 6-24. 
But understanding what the apprenticeship method was and appreciating that it was used by all the Protestant denominations in Canada does not give us an answer to the question, "Why was this method of ministerial training abandoned at some time after 1850 for a new type of training in a theological college which was situated on a university campus? And, why did this change take place at roughly the same time as law and medicine abandoned their apprenticeship systems and moved onto university campuses?"

Most of the major studies of this question in other countries such as Brian Heeney and Anthony Russell for Great Britain and Daniel Calhoun and Donald Scott for the United States have emphasized that underlying the transition from an apprenticeship system to the theological college there was a shift in the conception of ministry from an office to a profession which was precipitated partly by the separation of church and state and partly by industrialization, for all industrializing societies have become professionalizing societies ${ }^{11}$. Unfortunately, the insights of these excellent studies have never been applied to Canada because it has not been generally recognized that the apprenticeship system was in use in Canada and because no one has given a clear definition of what constitutes a theological college.

Robert Wood Lynn has provided a definition of the theological college which has been used by Bob Handy and has received wide acceptance by other historians working in this area. The four essential characteristics of a theological college as outlined by Lynn are: "a three year academic programme, a resident faculty of three or more, an institution independent of the colleges [or universities] and designed for the post-collegiate [or post baccalaureate] training of clergy"12. Andover Seminary, established in 1808 , was the first theological college to have these characteristics and it was followed four years later by Princeton Theological College. Because they were the first to be established these

11 See Brian Heeney, A Different Kind of Gentleman: Parish Clergy as Professional Men in Early and Mid-Victorian England, (Hamden, Connecticut: Archon Books, 1976); Anthony Russell, The Clerical Profession, (London: S PC K, 1980); Daniel H. Calhoun, Professional Lives in America: Structure and Aspiration, (Cambridge, Mass.: Harvard University Press, 1965); Donald M. Scott, From Office to Profession: The New' England Ministry, (Philadelphia: University of Pennsylvania Press, 1978). See also Alan Haig, The Victorian Clergy, (London, Croom Helm, 1984).

12 Robert Wood Lynn, "Notes Toward a History: Theological Encyclopedia and the Evolution of Protestant Seminary Curriculum, 1808-1968," Theological Education, 17:2 (Spring 1981), 118-144. 
two seminaries did a considerable amount of experimenting with curriculum before they both adopted the four-fold programme of Bible, Historical and Systematic Theology, Church History, and Practical Theology which has formed the core curriculum of the Protestant theological colleges up to our own time.

Now if we accept this definition of a theological college, the next question is when did this type of a school emerge in Canada? Since this question has not been asked by the historians of the various Protestant theological colleges in Canada, it is very difficult to get a satisfactory answer on the basis of the currently available literature. My guess at this point is that Knox College, Toronto was the first to assume this shape and that was partly as a result of the Free Church's convictions concerning the relationship between church and state. Unfortunately we don't have a major history of Knox College against which to measure my guesses. Partly because the Free Church was required to create new colleges for the training of their clergy in Scotland and partly because they did not want to have anything to do with Queen's, which was an Auld Kirk establishment, they were the first in Canada to be forced to think in new terms about theological education and in doing so Princeton became their model of a type of school which would meet their needs.

But if Knox met the criteria of a separate theological college from its inception in 1844, when did it meet the other criteria which Robert Lynn has established? On the matter of a faculty of three or more members teaching theology on a full-time basis, the history of Knox reveals that until 1861 there was never more than one individual who devoted his full attention to teaching. After the union of the Free Church and the United Presbyterian Church in 1861 and the amalgamation of the United Presbyterian Divinity Hall with Knox, there were finally three full-time professors: Michael Willis in theology, William Caven in biblical exegesis, and John Proudfoot in homiletics, pastoral theology and church government. As to when the Arts degree became an entrance requirement for theological education, it appears that the Congregationalists were the first to require a B.A. degree from McGill as a prerequisite for theology in 1876. Two years later Presbyterian College, Halifax made the Arts degree a prerequisite for theology, but Knox remained ambivalent on this question until the 1880 s because until then it had a preparatory programme for those without B.A.s. The Methodists, of course, took students with high school matriculation directly into their theological schools and well into the twentieth century individuals, like Gordon Sisco, took their theological training first and then after several years in the pastorate they came back to take an Arts degree. 
The Congregationalists again appear to be the first to have adopted the four fold curriculum and they had this in place by 1855 . The Presbyterians had adopted a similar programme by the 1860s. The Methodist curriculum, however, did not take this shape until well into the twentieth century ${ }^{13}$. A further difference between the Methodists, Presbyterians and Congregationalists was that the latter two required Latin, Greek, and Hebrew from their ministerial candidates while the Methodists did not. It was not until 1881 that Knox received degree granting powers and it was not untıl 1889 the Anglican coileges were ailowed to grant $\bar{B} . \bar{D}$. and $\bar{D} . \bar{D}$. degrees. From this all too brief survey, it seems possible to conclude that sometime between the 1860s and the 1870 s theological colleges, which conform to Lynn's criteria, began to emerge in Canada in most of the Protestant denominations. The question of when they began to see themselves as professional schools is more difficult to answer because in 1840 Adam Lillie, in his address before the Congregational Academy in Toronto, refers at least twice to the "professional education of ministers" and yet, it is not until the 1880s that the Protestant theological colleges begin to grant the B.D. degree as a professional degree ${ }^{i 4}$. Thus much more work is required before it will be possible to apply the insights of British and American scholars conerning the significance of the shift from the apprenticeship system to the theological college.

\section{III}

There is, however, another way of looking at the emergence of the theological colleges as professional schools and that is by seeing them in relation to the development of the Bible Colleges. The two main figures in the establishment of the Bible Colleges as institutions of higher education, as Harold W. Boon has pointed out, were Albert B. Simpson and Dwight L. Moody15. Simpson (1843-1919) was a Canadian Presbyterian from Bayview, Prince Edward Island who was baptized by John Geddie, the

13 On the question of curriculum see Nora L. Hughes, "A History of the Development of Ministerial Education in Canada from Its Inception until 1925 in those churches which were tributary to the United Church of Canada," (Ph.D. Thesis, Divinity School, University of Chicago, 1945), 52-55.

14 At the opening of the Congregational Academy in Toronto on September 11, 1840, Adam Lillie gave an address on the "Nature and Importance of Ministerial Education." It was a powerful address which clearly set forth the Congregationalist's commitment to an educated ministry. It was later published together with an address of Rev. W.P. Wastell of Hamilton. See A. Lillie and W.P. Wastell, Ministerial Education. Two Discourses delivered in the Congregational Chapel, Toronto, on the Occasion of the Opening of the Congregational Academy, (Toronto: Leslie Brothers, Publishers, 1840).

15 Harold W. Boon, "The Development of the Bible College or Institute in the United States and Canada since 1880 and its Relationship to the Field of Theological Education in America," (unpublished D.Ed. thesis, New York University, 1950). 
first Canadian Presbyterian missionary. In 1865 he graduated from Knox College and held pastorates in Hamilton, Ontario; Louisville, Kentucky; Thirteenth Street Presbyterian Church in New York city. In 1881 he resigned from the Thirteenth Street Church and began independent evangelistic work which eventually resulted in the formation of a new denomination, the Christian and Missionary Alliance. In his evangelistic work, Simpson discovered that many young people were offering themselves for missionary service who did not have the advantages of a good secular education and for a variety of reasons were not in a position to spend seven years in college and seminary in order to qualify as missionaries. Thus in 1883 Simpson established the first Bible College in North America which was called the Missionary Training College. Again as a rsult of his evangelistic work Dwight L. Moody arrived at similar conclusions in 1886 when he laid the foundations for the Moody Bible Institute which was designed to provide training for men and women who wished to enter "intermediate spheres of Christian work which lie between the ministry and the laity."

In all cases, those who established Bible Colleges were clear that they were not establishing seminaries or theological colleges for these were seen as professional schools which required college degrees for admission. Their intention was to train those who did not have college degrees for missionary work and evangelistic service. As a result, there was no attempt to affiliate these institutions with universities or to seek degree granting powers for these schools. Once this is understood, it becomes clear that the Bible Colleges could not have developed until it was apparent that the theological colleges had become professional schools for the training of clergy. So the development of the Bible Colleges give us a clue as to when contemporaries believed that such institutions in fact existed.

According to Ron Sawatsky, there were three Bible Colleges founded in Canada prior to the establishment of the Toronto Bible Training School in 1894. The first was the Mission Training School in Niagara Falls which was established in 1885 . The second was the Christian Intitute which was established in Toronto by Alfred Sandham and the third was the Toronto Missionary Training School founded by John Salmon in 1893. All of these schools had close connections with the Christian and Missionary Alliance and there is some evidence that Elmore Harris of Walmer Road Baptist Church in Toronto believed that schools sponsored by this new denomination could not properly represent the evangelical community in Toronto. Therefore, he established the Toronto Bible Training School which was dominated by Baptists and Presbyterians but also had Methodists and Anglicans among its early leaders, and unlike most other Bible Schools in 
Canada it appears to have been a lay training instute for the Canadian mainline Protestant denominations until well into the twentieth century ${ }^{16}$.

Like the theological colleges, the Toronto Bible Training School adopted a three year programme which focused on the "devotional" rather than the "critical" study of the Bible and provided courses in "all the subjects that are found in the curriculum of the average theological seminary" 17 . But although it offered a full theological curriculum, the Toronto Bible College was clear about its role as "a trainer of laypeople" which in their view "did not overlap or interfere with that of the denominational [theological] colleges"18. Using a military analogy, principal John McNicol saw the theological colleges as training facilities for the officers of God's army and the Bible Colleges as the training centre for the rank and file of that army. The fact that many of the newer and smaller denominations in Canada were prepared to ordain graduates of the Bible Colleges, however, meant that about ten percent of the Toronto Bible Training School's graduates did eventually end up in the ministry. This trend became more marked after the emergence of two-party Protestantism in Canada during the 1920s and 1930s. Moreover, following World War II the pressure built up for a transformation of the Bible Colleges into theological colleges for evangelicals. To move into twentieth century developments, however, is to move away from the point I wish to make.

Everyone has assumed that they know what a theological college is and that it is easy to establish the origins of these various schools. What I've been trying to suggest, however, is that on the basis of the currently available Canadian literature it is not possible to answer even the most elementary questions about the Canadian Protestant theological college. Thus we are not in a position to understand its development and we never will be until we can see it in relation to the other forms of theological education which were available to Canadians in the nineteenth century. For the theological college only comes into focus when it is seen in relation to the apprenticeship system which preceeded it and the Bible College which developed after the theological college had become an identifiable professional school. Finally, I do not think that we will be able to make use of the insights of the English and American literature concerning the

16 See Ronald George Sawatsky, "Looking for that Blessed Hope": The Roots of Fundamentalism in Canada, 1878-1914, (unpublished Ph.D. thesis, Uiversity of Toronto, 1985).

17 John McNicol, "Principal's Report," Recorder, 26 (June 1920), 4: cited by John Gordon Stackhouse, Jr., "Proclaiming The Word: Canadian Evangelicalism Since The First World War," (unpublished Ph.D. thesis, University of Chicago, 1987), 64.

18 Ibid., 70. 
social significance of the shift from an apprenticeship system to a professional school until we can accurately date the emergence of the theological college in Canada. The same holds true for the Bible College, because I do not think we can grasp its social significance unless it is seen in relation to the theological college and the impact of late nineteenth century revivalism with its emphasis on Christian missions. 